\title{
Private Schooling and Fayol's Principles of Management: A Case from Nepal
}

\author{
Chandra Sharma Poudyal* \\ The University of Waikato, Hamilton, New Zealand
}

\begin{abstract}
Henri Fayol is popularly known as the founder of administrative management for his contribution to the field of management. Although his principles of management are termed as classical management theory, the principles are still applicable in the field of management. In this paper I explore the issues of management and ownership in two private schools in Nepal using Fayol's principles of management.

The data were collected from two private schools using a case study approach. I conducted semi- structured interviews with teachers, administrators and principals of two private schools. In the case study schools, the owners were also working in the capacity of principal of the school and hence the term owner/ principal has been used in this paper. The owners/principals were taken as the participants to represent the voice of the employers while the teachers were taken to represent the voice of the employees. Similarly, the administrators in this study represent the voices of both the employer and the employees of the school.

This study suggests that when management and ownership are not separated, there is a concentration of power. The power concentration in individual or group of owners gives rise to a number of management related issues such as unequal distribution of authority and responsibility, role ambiguity, negative motivation and conflict of interest. Fayol's principles of authority and responsibility, initiative, subordination of individual interest to group interest, stability of tenure of personnel and spirit of cooperation have been used in this paper to explain several issues of management and ownership that emerged from the case study.
\end{abstract}

Keywords: Henri Fayol, management, private schools, power, interest

\section{Introduction}

Schools in Nepal are generally of two types - public and private. Public schools receive regular government support and are required to follow the government rules and regulations in school management. Private schools on the other hand, do not receive any support from the government and are managed by themselves though they 
are required to follow some government rules like they have to follow government prescribed curriculum and textbooks and students in private schools appear national examinations conducted at the end of grade ten. These private schools are under the ownership of individuals or groups of people who make investment and are profit oriented. Some private schools are also under the trusts which are supposed to be notfor-profit.

Because of perceived quality education many parents are attracted to private schools and send their children to these schools despite their high fees (Caddell, 2009). English medium instruction, better pass rate of students in the national level examinations, regular teachers attendance, smaller teacher-student ratios are some of the reasons behind the popularity of private schools in Nepal (Caddell, 2005; Save the Children, UK, South and Central Asia, 2002; Shields \& Rappleye, 2008; Standing \& Parker, 2011; Vaux, Smith, \& Subba, 2006). Despite their success in attracting parents, these profit-oriented private schools are often blamed for their management inefficiency (Carney, 2003). In these schools, the owners are usually the principals and the school administration is run on the words of owners instead of rules and regulation (Sigdel, 2008). Teachers are appointed without following state regulations and are poorly paid. These schools exclude most of the stakeholders (parents, teachers and other non-owner staff) from the decision making process (Carney, 2003). There are thus several issues related to management of private schools in Nepal. Given these issues, the so called success or quality of these private schools has become questionable. In such a context, this paper is an attempt to explore issues related to management of profit-oriented private schools using Henri Fayol's principles of management and is based on the case study of two such schools in Kathmandu. Before discussing Fayol and his principles of management and my case study schools, I begin this paper with a brief discussion of the development of modern school education in Nepal.

\section{History of Modern Schooling in Nepal}

The history of modern schooling in Nepal began with a school established by the then Prime Minister for family purpose. Janga Bahadur Rana, a Rana Prime Minister, recognized the need of education after his visit to England and established Nepal's first school, Durbar High School, which was an English medium school meant only for the royal family (Government of Nepal: Ministry of Education, 2009; Khaniya, 2007; Kulung, 2008; Sigdel, 2008). Thus, the schools established before 1950 were confined to the children of the royal family. After the political change in 1950, people started establishing schools on their own initiatives instead of waiting for the government to establish schools for their children. Such schools were called non-government schools rather than private schools (Khaniya, 2007; Lamichane, 2008).

The government introduced Education Act 2028 (1971) and nationalized all the existing schools, thus hindering the growth of private sector education (Khaniya, 2007; Kulung, 2008). However, it was soon realized that the government cannot 
provide education to all the children and the Education Act 2028 (1971) was amended in 1980. This once again made a provision for private sector involvement in education. Thus, initially private schools as organizations in the education sector in Nepal, as in many South Asian Countries, came as an alternative to meet the excess demand of education. Since mid-1980s there has been rapid growth in the number of private schools in Nepal (Save the Children, UK, South and Central Asia, 2002). The political change of 1990 further facilitated the process of privatization of education in Nepal. This has resulted in mushrooming of private schools, especially in the urban centers of the country (Khaniya, 2007). The Seventh Amendment of the Education Act 2028 (1971) in 1992 made a provision for registering existing private schools either as private limited company or as trust (Dhungel, 2008; Gautam, 2008; Khaniya, 2007). This has changed the traditional notion of seeing school as not-for-profit organization. As a result of registration of private school as business organization (private limited company), several issues related to management of private schools arose.

\section{Henri Fayol and Management}

Management is an activity not confined to particular member of an organization; it is spread among members of an organization (Fayol, 1949). Henri Fayol (1841-1925) was the first person to advocate management education that laid the foundation of management as both discipline and profession (Pryor \& Taneja, 2010). Henri Fayol, popularly known as the founder of administrative management, developed his theory on the basis of his practical experience in the field of management (Fells, 2000; Pryor \& Taneja, 2010). Although Fayol began to formulate his administrative theory ideas as early as 1900, his ideas became popular after its English translation in $1949^{1}$ (Wren, 1979). Henri Fayol (1949, p. 3) divided the activities of an enterprise into six different categories:

i) Technical activities related to production, manufacture and adaptation

ii) Commercial activities such as buying, selling and exchange

iii) Security activities which include protection of property and persons

iv) Accounting activities related to stock taking, balance sheets, costs and statistics

v) Financial activities which includes collection and proper utilization of capital

vi) Managerial activities such as planning, organization, command, co-ordination and control

On analyzing these six groups of activities, Fayol found that the first five activities were well known during his time and the sixth activity, i.e. managerial activities was the most neglected one. Thus, Fayol concentrated his work on further development of managerial activities (Wren, 1979).

\section{Fayol's Principles of Management}

Fayol (1949, pp. 19-20) developed 14 general principles of management which he stated were flexible in nature. These 14 principles were: 
i) Division of work

ii) Authority and Responsibility

iii) Discipline

iv) Unity of command

v) Unity of direction

vi) Subordination of individual interests to the general interest

vii) Remuneration

viii) Centralization

ix) Scalar chain (line of authority)

x) Order

xi) Equity

xii) Stability of tenure of personnel

xiii) Initiative

xiv) Esprit de corps (Spirit of cooperation)

According to Fayol, these principles of management can be used to guide proper implementation of management processes such as planning, organizing, commanding, coordinating and controlling (Fells, 2000). Among Fayol's 14 principles of management, only a few of these principles are applicable to my present study. Thus, I am discussing those principles applicable along with participants' quotes in the subsequent section. In the meantime, I am discussing the relevance of Fayol's principles in the present study.

\section{Comparing Fayol with Taylor}

Henri Fayol developed his administrative theory of management during the time when there was a vacuum with regards to management theory (Pryor \& Taneja, 2010). Even though his original work Administration Industrielleet Generale was published in French in 1916, the English translation of his work was not available until 1949. Fayol is often compared with twentieth century management experts such as Taylor, Follet, Urwich and Weber (Parker \& Ritson, 2005, p. 176). However, F. W. Taylor is the management expert with whom Fayol is most commonly associated (Wren, 1995).

Taylor called his theory of management the principles of scientific management. In his principles, Taylor argued that managers need to actually know about the work before asking employees to do the work (Replacing rule of thumb by science), the employees/workers need to be paid as per their production capacity (Differential payment system), there needs to be harmony in group activity (Cooperation not individualism), the development of the organization is only possible with the development of the employee (Training and development of employee) and both employees and employer need to have positive attitude towards each other (Complete mental revolution) (Taylor, 1967).

Fayol and Taylor both contributed towards improving management practices. However, they have different focus. Fayol started his work from the top level management and moved downward while Taylor started his work from the shop 
level and moved upward (Wren, 1995). In spite of such contemporary work, Fayol was overshadowed by Taylor in North America and even in his own country, France for sometime (Fells, 2000; Wren, 1995, 2003). After the English translation of his work, Fayol's principles of management spread to different parts of the world. Citing quotation from Honda Executives ("when it comes to management American do not practice what they preach"), Archer (1990) noted that in contrast to American, Japanese management success is largely attributed to the adoption of the practice and style related to Fayol's principles of management. Such practices includes cross training, job transfer, JIT (Just in Time) of inventory management and decision making authority delegated to the employees at the operation level. Thus, Fayol's principles of management are still applicable in management and they will continue to provide general perspectives for practicing managers. These principles also act as instructional tools in the field of management (Rodrigues, 2001).

\section{Comparing Fayol's Work with the Contemporary Management Model}

Fayol's work has been compared with different contemporary management models from Mintzberg, Kotter and Hales (Fells, 2000; Pryor \& Taneja, 2010). Wren (1995) argues that an understanding of Fayol's work provides an important landmark in the development of management theory. Although Fayol's work provided a conceptual basis of teaching management and important landmark for management theory, contemporary management experts such as Mintzberg and Kotter criticized Fayol's ideas on different grounds.

Mintzberg (1975, p. 49), for example, noted that 'the classical view says that managers organize, coordinate, plan and control; the facts suggest otherwise, thus creating 'folklore' of management. He further added that classical view introduced by Fayol failed to address what actually managers do. He observed five chief executives from different types of organizations to explore the question, "What actually do managers do?" He argues that what he observed did not fit with Fayol's ideas of management. Moreover, he described managerial jobs in terms of three different roles or set of behaviors: i) interpersonal roles (as figurehead, liaison and leader) ii) informational roles (as monitor, disseminator and spokesman) and iii) decisional roles (as entrepreneur, disturbance handler, resource allocator and negotiator) (Mintzberg, 1989).

Kotter $(1982,1999)$ studied a group of successful general managers in nine corporation located across different cities in the United States between 1976 and 1981. $\mathrm{He}$ found that top managers do not plan and organize systematically as indicated by classical theory of management. Managers face several challenges related to uncertainty, diversity, a huge amount of relevant information and diverse set of people over which they (managers) have little direct control. Highlighting the discrepancy associated with classical management theory, Kotter (1999, p. 148) noted: 
Figuring out what to do... getting things done through large and diverse group of people... are severe challenges with powerful implications for the traditional management functions of planning, staffing, organizing, directing and controlling. To tackle those challenges, effective general managers rely on agenda setting and network building.

Although Kotter highlighted the challenges related to management functions of planning, staffing, organizing, directing and controlling, he still believes that they are the functions of management as suggested by Fayol. Fells (2000) also compares Fayol's work with contemporary management models from Hales, Mintzberg and Kotter and consequently argues that Fayol's work is interrelated with contemporary management model at the basic level. Mintzberg and Kottter consider management as the work of managers. They both studied management by studying the work of individuals working in the managerial positions. However, my argument in this paper is that management is not confined to the people at the top; it is a group activity and thus it spreads among different members of the organization. Therefore, I am using Fayol's principles of management in this study.

\section{Study Context}

The present study is an exploratory study. The findings of this study are based on the responses of ten participants from two schools selected for case study. It is more concerned with how things work within these two Nepali private schools and within the ten research participants who voluntarily took part in this study.

This study was conducted using a qualitative case study approach in two private schools in Kathmandu. The first case study school was a school registered as a Private Limited Company. It was a school owned and managed by a single person who was also the principal. Therefore, the term owner/principal has been used throughout this paper to refer to this principal to highlight the dual roles. After completing my initial data collection on the first case study school, several issues ${ }^{2}$ emerged and to explore such issues further, I approached a second school. The second school was also registered as a Private Limited Company, owned and managed by a group of people. Each of the primary owners was working in different management positions; one was the principal (owner/principal). There were also secondary owners in the second case study school. This included some of the teachers and other staff.

The participants of the study included the owner/ principals, administrators and teachers of the schools. The owner/ principals represented the voices of the employers of the schools. The administrators represented voices of both employer and employee. Some of the administrators of this study had partial ownership while others had developed the feeling of ownership due to the positions they occupied in the school. The teachers represented the voices of the employees. 


\section{Data Collection}

The data for this study were collected from April to June, 2011.Semi- structured interview with open ended questions were used for data collection within a qualitative framework (Hoepfl, 1997; Kvale, 1996). A list of interview guides were prepared in advance and given to the participants along with the information sheet. The interviews were conducted once the informed consent forms were signed. Each interview was digitally recorded and field notes were also taken. Each interview lasted about thirty to sixty minutes. I began each interview with more general questions like, 'how do you feel working as a teacher/administrator/ principal of a private school in the present context?' to enable the free flow of conversation during the interview. I ended the interview with the question, 'Do you have anything to say that I missed out?'

I transcribed the raw interview data myself. This maintained the anonymity of the participants and increased my exposure to the data (Skene, 2007; Sullivan, 1998). I listened to the recording four to five times before developing the transcripts of the interview. Each interview took me about three days to transcribe. The interview transcript was then given to the participants along with the letter for the release of the transcript for use. In that letter, participants were invited to choose one of the following options: (a) accepting the transcript as a raw data without change, (b) accepting it after incorporating the changes they wished to make; or (c) withdraw from the research.

Most of the participants agreed to return the transcript along with the letter after two days. Accordingly, I returned to each school to meet the participants and collect their transcripts and letters. None of the participants withdrew from the study after they got the transcript of the interview; three of them requested changes before accepting the transcripts and seven accepted the transcripts as raw data without changes. When they returned the interview transcript along with the letter for the release of use of the transcript, I conducted a follow up interview as I had already indicated that would happen. The follow up interview lasted about twenty to thirty minutes. In this interview, I clarified anything that was confusing to me in the transcript.

\section{Data Analysis}

The interview data were analyzed using Seidel's (1998) model of data analysis. Seidel argued that qualitative data analysis is a process of 'noticing, collecting and thinking about interesting thing' (Seidel, 1998, p. 1). In addition to interview, the data sources also include informal observation during the interview and documentary sources. This created a record of the things which I noticed during the data collection phase. This record of the material was read again and again to enter into the world of participants and feel their experiences (Corbin \& Strauss, 2008). During this stage, different questions as suggested by Corbin and Strauss $(2008$, p. 72$)$ were asked.

Guiding questions that guided me during the interview, documents collection and analysis;

Sensitizing questions that enabled me to think about what the data is indicating. 
The issues that emerged out of noticing of data from the first school led me to think and then choose the second school (Seidel, 1998). Thus, the process of moving back and forth between empirical data and emerging analysis was involved in the process of data analysis.

\section{Findings}

This section discusses the finding of this study in the light of Fayol's principles of management. The results of this study in relation to Fayol's principles of management are presented below along with the supporting quotes from the research participants.

\section{Authority and Responsibility}

Authority is the right of superiors to give orders and power to maintain discipline whereas responsibility is the obligation of subordinates to obey the superiors. Fayol believed that authority and responsibility go together. Whenever authority is exercised, responsibility arises. So there needs to be a proper balance between authority and responsibility (Fayol, 1949; Pryor \& Taneja, 2010; Wren, 1995, 2001).

Even though Fayol argued in his principle that there needed to be proper distribution of authority in the organization for maintaining balance with responsibility, the findings of this study suggested otherwise. Some lower level management roles such as head of department, primary and secondary in- charge, vice principal and coordinator in both schools were staffed by non- owners. Those working in these positions felt that they had responsibility without authority. This alludes to the concentration of power on the owners or group of owners due to non- separation of management and ownership. A secondary teacher at the first case study school described the scope and role of the secondary in-charge:

We have a secondary in-charge in our secondary block. But the role/ authority and scope of this position is not clear. We see the person in this position just acting as an agent of the owner/ principal. The person does the work of reporting day to day activities of the secondary block to the owner/ principal. The person is acting as a medium for the owner/ principal to oversee our activities instead of the owner/ principal directly doing this.

The primary coordinator (administrator) of the same school stated about the scope and role of his position:

As a co-ordinator, I handle the accounts section; take parents' complaints, suggestions and feedback; and arrange parents- teachers meeting. I report all the activities of the primary block to the owner/ principal twice a day in person and other times via telephone as per the situation.

Similarly, the owner/principal of the same school stated about the overall management of the school:

The primary co-ordinator reports to me twice a day about the activities of the primary block. Whenever there is any problem in the primary block, the coordinator reports to me via telephone and I give direction to act. Similarly, the 
secondary block in-charge reports to me twice a day about the activities of the block.

The quotes from the owner/principal and staff of the first case study school indicate that the owner/principal retains all the authority and the non- owner staff have responsibility without proper authority. The non-owner staff who are given different roles such as secondary in-charge and primary coordinator need permission of the owner/principal for each and every activity. They do the work of reporting every activity to the owner/principal which suggests that the owner does not delegate any part of management of the school. Technique of surveillance involving network of relationship from the owner/principal to the non-owner staff occupying different positions is being used for the purpose of power concentration (Foucault, 1995).

Although the structure of the second case study school was different, similar findings were noted. A secondary teacher said that the head of the departments have heavy workloads without the capacity to make decision as power is not delegated to them from the owners. Similarly, another secondary teacher said:

Even though it is theoretically said that employers need to take employees' suggestion and feedback but in practice the story is different. It depends on ... employers' thinking.

The quotes from both the teachers indicate that the owners retain authority and the non-owner staff are given more responsibility and less authority. This suggests that there is unequal distribution of authority and responsibility among owners and nonowner staff. Thus, power, resources, decision making authority and communication are concentrated in the school owners.

\section{Remuneration of the Personnel}

Remuneration of the personnel is the money employer pays in return for work to the employees. Fayol argues that remuneration/wages/ salary of the personnel working in the organization needs to be fair to provide satisfaction to both the employees and employers. It depends on general economic condition of the organization, cost of living and the capacity of the individual employees (Fayol, 1949; Pryor \& Taneja, 2010; Wren, 1979, 1995).

Money paid for work is one of the undisputable sources of desire for work. Money can be exchanged for many commodities necessary for the survival and comfort of people (Vroom, 1995, p. 36). Quotes from most of the employees of the first school suggested that they are not satisfied with the remuneration they are earning from their work. In this regard, a female teacher working in the primary level said: "The salary/ remuneration I am getting working here is not enough for my survival. Even though I am working, I need support from my husband." Another female primary teacher of the same school also said that the salary or remuneration she is getting from work is not enough for her survival. The quotes from the female research participants of the first school suggested that even though they are not satisfied with the financial remuneration 
from work, they are still working. Thus, their working in the school may be interpreted in terms of reasons other than financial incentives. In addition to financial incentives, there can be other reasons for work such as expenditure of energy, production of goods and services, social interaction and social status of work (Vroom, 1964, 1995). The secondary teacher and the administrator of the same school have somewhat different ideas about the remuneration. In this regard, the secondary teacher said:

Now teachers working in private schools have established teachers unions and due to this, the economically sound schools are providing satisfactory remuneration to their employees. This has influenced smaller schools like ours and they are trying to provide satisfactory remuneration to their employees even though it has not been achieved yet.

Even though the secondary teacher said that most private schools are working towards satisfactory remuneration, he still believed that they are not getting remuneration as per the service they are providing to the schools. The administrator of the school said, in regard to remuneration, that the school owners these days are working towards collective benefit of the staff. However, it was not clear what he meant by collective benefit of the staff. Similarly, the owner/principal of the same school said the following things about remuneration of the personnel:

Teachers working in the private schools these days are asking for remuneration equivalent to public school system. But small schools like ours are unable to fulfill their demands. Due to this, there is a situation of conflict within the schools.

The quotes from the staff and owners of the first school indicate that the remuneration of the personnel working in the school is not fair. The remuneration is not based on cost of living as suggested by most of the staff, "we cannot survive with the salary we are earning from work". But it appears to be based on the perceived importance of the employees to the school and general economic condition of the school. Since the students of the secondary level are the ones appearing in the School Leaving Certificate (SLC) examination on the basis of which schools in Nepal are evaluated, the owners perceived that teachers working in the secondary level are more important staff than those working in the primary level.

In the second case study school, the situation of remuneration of personnel was somewhat different from the first school. Talking about remuneration, an administrator of the second school said:

Even though the school has not yet been able to provide remuneration equivalent to public school system, the teachers and other staff are convinced that depending on the increase in student enrolment, salary will also increase. Each year, remuneration of the staff is determined through mutual discussion. Similarly, a secondary teacher in regard to remuneration stated: Our school is trying to narrow the gap between our demands (remuneration equivalent to public schools) and actual remuneration they are providing us. Now, our school facilities including remuneration are becoming more transparent and owners give satisfactory justification when they cannot provide 
facilities commensurate with public schools.

However, the owner/principal of the school said the following things about the remuneration of personnel and present demand of the teachers:

Private school teachers' facilities including remuneration are based on the mutual agreement between the teachers and the school owners at the time

of contracting the employment. There is no point in arguing later about the facilities equivalent to public school system.

The quotes from the staff and owners of the second school suggest that the staff are somewhat satisfied with the remuneration they are getting in return for their work. The situation of transparency of the remuneration appears to develop positive attitude in the staff towards the school. The remuneration of the personnel of the second school also seems to be based on the economic condition of the school. However, in addition to monthly or weekly wages, financial remuneration these days include wide range of other benefits such as retirement programs, life and health insurance plans and job security (Vroom, 1964, 1995). Initiative among staff of second school was not seen due to lack of other component of financial remuneration.

\section{Initiative}

According to Fayol, initiative as a principle informs individuals working in the organization to display their interest and efforts towards the organization. Initiative of all represents the strength of the organization and so each individual working in the organization needs to take initiative towards maximum utilization of his/her capacity (Fayol, 1949; Fells, 2000; Rodrigues, 2001; Wren, 1979, 1995).

In order to develop initiative towards organization, the individual working in the organization needs to be positively motivated towards work. Positive attitude towards organization or work indicates satisfaction of the employees where negative attitude represents a source of dissatisfaction of the employees towards the organization or work itself (Vroom, 1995, p. 115). Quotes from the research participants of both the schools suggest that they are negatively motivated towards the work. In this regard, a female teacher of the first school working in the primary level said, "I have worked here for 14 years and the only thing I gained is experience. Still I need to work here due to lack of other options. "Similar ideas were expressed by another female teacher working in the primary level of the same school:

Day by day, inflation is increasing but our salary is not increasing as per the inflation. I cannot survive with the salary I am earning from this school but still I need to work here due to lack of other options.

Both of these teachers stated that they are working in the present job due to lack of other options and once they get any better options they will naturally change their jobs. They seem to be taking the job as a platform. Similar ideas were expressed by the administrator of the first school:

School owners are happy at closing down the school but what about our future.

We have worked here for more than 15 years and spent most of our youth 
working here. If people can take loan for personal purpose, why don't school owners take loan for investing in the school?

The staff participants of the first school seemed to be negatively motivated towards their work. Due to this, there was lack of initiative from these people and in such situations it is very difficult to imagine the employees to be working towards maximum utilization of their capacity.

Now, coming to the second school, more or less similar situation was noticed from the staff participants' quotes. A female teacher of the second school stated:

We work in private schools for 15-20 years and after we leave we have nothing to take. We get remuneration if we can work, if we cannot work for some reason we get nothing. We need to work harder for our job security and due to this private school jobs are taken as a platform.

Similarly, another female teacher of the same school said following things about working in private school:

There are lots of challenges working as a teacher in private schools of Nepal.

We don't have job security; change of school owners may force us to leave the job.

Both the staff participants of the second school argued that jobs in private schools are not secured and they cannot work with confidence in such a situation. There is always fear of losing their jobs. They only get paid for their work and in the event of any unavoidable circumstances they would be left penniless. Similarly, a secondary teacher of the same school in this regard said:

There is a vast difference between working by force and working by satisfaction

from within. Still the private schools are not able to create an environment in which we teachers can believe that jobs in private schools are also dignified.

The quotes from different staff participants of the second school suggest that they still feel that they are not secured in their jobs. This is more aligned to Fayol's principle of Stability of tenure of personnel. In this principle, Fayol argued that the organization needs to avoid high rate of employee turnover because training of new employees is expensive and time consuming (Rodrigues, 2001). When there is stability of tenure of personnel, the people working in the organization feel a sense of job security. However, this study suggests that the situations in the case study schools are different from what Fayol suggested should be. The employees/staff feel that private schools are working as a business organization and they really do not care about employee satisfaction. As a result employee initiative towards work is not productive and there is less chance of making use of maximum capacity of each employee for the strength of the organization.

\section{Subordination of Individual Interest to General Interest}

Fayol argue that the interest of one employee or group of employees working in the organization should not be above the interest of the organization. Whenever there is conflict between the interest of the organization and that of individual employee, the employee should be ready to give up his/her interest for the sake of organization (Fayol, 
1949; Rodrigues, 2001; Wren, Bedeian, \& Breeze, 2002; Wren, 1979).

The staff participants of this study perceived that the interest of the school and that of school owners are the same. Due to this, there is conflict of interest between the school owners and the staff participants of this study. An administrator of the first case study school said:

School owners usually argue that even though they invested a lot in school, they are not earning any profit. Now they seem to be ready to close down the school and earn the rent from the building. They don't think about our future; we spent almost all of our lives in this school.

In this respect, the owner of the same school said:

Our school is a small school run under individual investment. We are facing difficulties competing with the large schools being run from the investment of a large number of people. At the same time, teachers working in private schools are demanding facilities equivalent to public school system. Due to this, we are now facing difficulties for survival.

In this regard, a secondary teacher of the same school said:

Private school owners now need to think seriously about our demands. If they cannot provide us with facilities as per our demand they can either close down the schools or merge it with other schools. There is no point in operating the schools if they cannot fulfill teachers' demands.

The quotes from both the owner and staff of the school suggest that both groups are working towards the fulfillment of their self-interest. The administrator argued that owners are working towards earning more profit and they are ready to close down the school if they cannot earn profit from school operation. On the other hand the, owner argued that they are facing difficulties in the operation of the school due to competition with larger schools operated with a huge investment and teachers demand for increasing their facilities. Similarly, the secondary teacher of the same school argued that there is no point in operating the school if their demands cannot be fulfilled.

In this regard, a female teacher of the second school argued that the teachers working in the private schools are not happy with their jobs. When they become unable to work, they will have nothing. These teachers spend all of their lives in the school and when they face any problem in their lives, they are left with nothing. The owner/ principal of the same school in this regard said:

Private schools are run on their own. It is not fair to demand for facilities equivalent to public school system. Before entering into the employment, each and every teacher agrees on the facilities of the school and it is not fair to ask for public school equivalent facilities later on.

A secondary teacher of the same school, in this regard, said:

Private schools are converted into lucrative business. Due to this, the concept of employee and employer arose. It is common for the employer to give as less facilities as possible to the employee.

Both the employees (represented by non-owner staff) and employers (represented by school owners) seem to be working towards fulfillment of their personal interests. The schools owners are working towards increasing profit by decreasing the 
facilities of the staff as much as possible. On the other hand, the non-owner staff are working towards increasing their facilities. The interests of the individual employees and employers are given priority and the interest of the organization is taken as a secondary interest. The school staff perceived that the school belongs to the owners and they need to draw out as much resources as they can from the school so that they can fulfill their personal interest. The school owners perceived that the school staff are being paid for their work and they need to work as per the desire of the owners. Thus, there is lack of cooperation between the employees and employers which hinders the smooth operation of the school. Every member seems to be working towards individual interest instead of the interest of the organization. So, the interest of the individual is given priority compared to the interest of the organization. In such a situation, Fayol's Principles of Esprit de Corps or Spirit of Cooperation needs to be considered. In his principle of Esprit de Corp, Fayol argued that harmony among the members of the organization represents the strength of an organization and a step towards organizational effectiveness and success (Fayol, 1949). However, this study found that conflict of interest among the members of the organization is preventing harmony in the organization. This has created a situation where there are fewer chances of high morale and unity among the employees (Rodrigues, 2001).

\section{Summary and Discussion}

The results of this exploratory study indicate that management and ownership of both the schools are not separated and they are confined to owners. Thus, management of both the schools is not spread among different members of the schools as suggested by Fayol. This has resulted in the unequal distribution of authority and responsibility combined with unsatisfactory remuneration of the personnel. There is prevalence of negative motivation among the staff working in both schools. The positive attitude towards the school, a cause of satisfaction, is lacking and it is superimposed by negative attitude or dissatisfaction of the employees.

The extent of negative attitude toward the school was comparatively less in the second school. The first school was the school owned and managed by a single person. The staff perceived that everything about the school was solely related to the school owner. The second school was owned and managed by a group of owners. The school also had recently introduced the idea of secondary partners among the staff and this seemed to have developed positive attitude in some of the staff having partial ownership. Yet, this has not spread among all the staff working in the school.

\section{Conclusion}

Non- separation of management and ownership in Nepali private schools has resulted in power concentration in school owners. Such power concentration has led to a number of management related issues such as negative motivation among non-owner staff, role ambiguity, unequal distribution of authority and responsibility and conflict of interest. Even though several lower level management positions such as head of 
department, primary in- charge and secondary in-charge are created and distributed to the non-owner staff, people occupying such positions perceived that they don't have proper decision making authority. This has created a situation of role ambiguity. The staff perceived that scope and authority of such positions are not clear to them. Lack of proper decision making power on the part of non-owner staff appears to develop a feeling of powerlessness among them. School owners have not delegated management to the non-owner staff, thus preventing management from being a group activity.

The need for 'complete change in the mental attitude' (Taylor, 1967, p. 100) of people working in the private schools arises in this situation. Both the owner and non-owner staff need to change their outlook towards each other. There need to be an environment of mutual trust and understanding among different groups of people working in the school. The spirit of cooperation as suggested by Fayol is possible in the event of change in attitude of different people working in the school. Instead of confining school management to the school owners with formal authority, it should be spread to each and every person working within the school system (Harris, 2003).

This study has introduced Fayol's principles of management and used some of these principles in understanding and investigating some management issues at two private schools in Nepal. It has used Fayol's management thought in exploring the management of private schools and therefore has significant contribution towards literature on management in general and private school management in particular.

\section{Implication and Future Research}

This study has explored some of the issues of private schooling in Nepal using Fayol's principles of management. The issues discussed are only based on Fayol's Principles of management. Thus, the results of this study can be theoretically generalized on the basis of Fayol's principles of management even though it has not used all the 14 principles of management suggested by Fayol. In addition to Fayol's principles of management, the issues of management of private schooling in Nepal can be considered using different theoretical lens. Thus, there is scope for further study on management issues in Nepali private schooling using different theoretical lens other than Fayol's principles of management.

\section{Notes}

1 The English translation of his original work, Administration industrielle et generale (French) by Coubrough appeared in 1930. One of Fayol's other papers; "The Administrative Theory of the State" was translated in 1923 and published in America in 1937. However, American got opportunity to thoroughly expose to Fayol's theory only after English translation of Administration industrielle et generale in 1949 by Constance Storrs (Wren, 1979, p. 228).

2 One of the issues that came out from the first case study school is that schools under individual investment and ownership are struggling to fulfil teachers' demands and another issue was that even though there was widespread unionization of teachers, 
most of the teachers of first school did not join the teachers' union claiming that they (teachers' union) only have political motive.

A version of this paper was presented at 16th Annual Waikato Management School Student Research Conference on 23rd October, 2012 at The University of Waikato, Hamilton, New Zealand.

\section{References}

Archer, E. R. (1990). Toward a revival of the principles of management. Industrial Management, 32(1), 19-21.

Caddell, M. (2005). "Discipline makes the nation great": Visioning development and the Nepali nation-state through schools. In B. Veronique (Ed.), Manufacturing citizenship: Education and nationalism in Europe, South Asia and China (pp. 76-103). Oxford, England: Routledge. Retrieved from http://oro.open. ac.uk/2855/1/Caddell-Citizenship.pdf

Caddell, M. (2009). Private schools as battlefield: Contested visions of learning and livelihood in Nepal. In P. Bhatta (Ed.), Education in Nepal: Problems, reforms and social change (pp. 121-148). Kathmandu: Martin Chautari.

Carney, S. (2003). Globalisation, neo-liberalism and the limitations of school effectiveness research in developing countries: The case of Nepal. Globalisation, Societies and Education, 1(1), 87-101.

Corbin, J., \& Strauss, A. (2008). Basics of qualitative research: Techniques and procedures for developing grounded theory. London, Los Angeles, New Delhi and Singapore: Sage.

Dhungel, M. (2008). Gunashtariya sikshhya: Bujhai aa-aaphnai [Quality education: Different understandings]. In J. Subedi (Ed.), Kasima niji biddhyalaya [Assessing private schools] (pp. 31-46). Kathmandu: Education Journalists' Group and Action Aid, Nepal.

Fayol, H. (1949). General and industrial management (C. Storrs, Trans.). Kenya, Australia, South Africa, U.S.A. and Canada: Pitman Publishing.

Fells, M. J. (2000). Fayol stands the test of time. Journal of Management History, 6(8), 345-360.

Foucault, M. (1995). Michel Foucault's discipline and punish: The birth of the prison (A. Sheridan, Trans.). New York: Vintage Books.

Gautam, R. (2008). Samtaka dhristile niji biddhyalaya [Private schools and equity]. In J. Subedi (Ed.), Kasima niji biddhyalaya [Assessing private schools] (pp. 47-60). Kathmandu: Education Journalists' Group and Action Aid, Nepal.

Government of Nepal: Ministry of Education. (2009). Compendium on education policy in Nepal. Kathmandu: Author.

Harris, A. (2003). Distributed leadership in schools: Leading or misleading? Management in Education, 16(5), 10-13. doi:10.1177/089202060301600504

Hoepfl, M. (1997). Choosing qualitative research: A primer for technology education researchers. Journal of Technology Education, 19(1), 47-63.

Khaniya, T. R. (2007). New horizons in education in Nepal. Kathmandu: Kishor Khaniya. 
Kotter, J. P. (1982). What effective general manager really do. Harvard Business Review, 60(6), 156-160.

Kotter, J. P. (1999). What effective general managers really do. Harvard Business Review, 77(2), 145-159.

Kulung, M. D. (2008). Niji biddhaylayama pahunch ra sarokarwala ko bhumika [Private schools access and role of stakeholders]. In J. Subedi (Ed.), Kasima niji biddhyalaya [Assessing private schools] (pp. 11-29). Kathmandu: Education Journalists' Group and Action Aid, Nepal.

Kvale, S. (1996). Interviews: An introduction to qualitative research interviewing. London and New York: Sage.

Lamichhane, R. (2008). Sikshyama udarikaran ra bishwo byapar sangathanko prabhav [Liberalization in education and the influence of World Trade Organization]. In J. Subedi (Ed.), Kasima niji biddhyalaya [Assessing private schools] (pp. 7997). Kathmandu: Education Journalists' Group and Action Aid, Nepal.

Mintzberg, H. (1975). The manager's job: Folklore and fact. Harvard Business Review, 53(4), 49-61.

Mintzberg, H. (1989). Management: Inside our strange world of organizations. New York: The Free Press.

Parker, L. D., \& Ritson, P. A. (2005). Revisiting Fayol: Anticipating contemporary management. British Journal of Management, 16(3), 175-194. doi:10.1111/ j.1467-8551.2005.00453.x

Pryor, M. G., \& Taneja, S. (2010). Henri Fayol, practitioner and theoretician revered and reviled. Journal of Management History, 16(4), 489-503. doi:10.1108/17511341011073960

Rodrigues, C. A. (2001). Fayol's 14 principles of management then and now: A framework for managing today's organization effectively. Management Decision, 39(10), 880-889.

Save the Children, UK, South and Central Asia. (2002, September). Private sector involvement in education: A perspective from Nepal and Pakistan.Kathmandu: Author. Retrieved from http://resourcecentre.savethechildren.se/content/library/ documents/private-sector-involvement-education-perspective-nepal-and-pakistan

Seidel, J. (1998). Qualitative data analysis: The ethnograph. Retrieved from http:// www.engin.umich.edu/teaching/crltengin/engineering-education-researchresources/seidel-qualitative-data-analysis.pdf

Shields, R., \& Rappleye, J. (2008). Uneven terrain: Educational policy and equity in Nepal. Asia Pacific Journal of Education, 28(3), 265-276. doi:10.1080/02188790802270237

Sigdel, S. (2008). Byabasthapanma pani niji [Private management]. In J. Subedi (Ed.), Kasima niji biddhyalaya [Assessing private schools] (pp. 61-78). Kathmandu: Education Journalists' Group and Action Aid, Nepal.

Skene, C. (2007). Interviewing women: Using reflection to improve practice. Nurse Researcher, 14(4), 53-63.

Standing, K., \& Parker, S. (2011). The effect of the "People's War" on schooling in Nepal, 1996-2006. Education, Citizenship and Social Justice, 6(2), 181-195. 
doi: $10.1177 / 1746197911410376$

Sullivan, K. (1998). Managing the "sensitive" research interview: A personal account. Nurse Researcher, 6(2), 72-85.

Taylor, F. W. (1967). The principles of scientific management. New York: Norton.

Vaux, T., Smith, A., \& Subba, S. (2006). Education for all - Nepal: Review from conflict perspectives. Kathmandu: International Alert.

Vroom, V. H. (1964). Work and motivation. New York, London and Sydney: John Wiley.

Vroom, V. H. (1995). Work and motivation. San Francisco: Jossey-Bass.

Wren, D. A. (1979). The evolution of management thought (2nd ed.). New York, Chichester, Brisbane and Toronto: John Wiley.

Wren, D. A. (1995). Henri Fayol: Learning from experience. Journal of Management History, 1(3), 5-12.

Wren, D. A. (2001). Henri Fayol as strategist: A nineteenth century corporate turnaround. Management Decision, 39(6), 475-487. doi:10.1108/ EUM0000000005565

Wren, D. A. (2003). The influence of Henri Fayol on management theory and education in North America. Enterprises et Histoire, 34(3), 98. doi:10.3917/eh.034.0098

Wren, D. A., Bedeian, A. G., \& Breeze, J. D. (2002). The foundation of Henri Fayol's administrative theory. Management Decision, 40(9), 906-918. 